Novyie

professii

[New

professions].

(2021).

URL: https://narfu.ru/agtu/www.agtu.ru/ic/2otdelprofor/5d22998dda9bcb2e b3b43b956a05c8bbnprof.htm [in Russian].

Profesii maibutnoho: yaki spetsialisty budut zatrebuvani pisliazavtra [Professions of the future: what specialists will be in demand the day after tomorrow]. (2019).

URL: ttps://life.pravda.com.ua/columns/2019/02/19/235691/ [in Ukrainian].

Professii buduschego, $\mathrm{k}$ kotoryim stoit prismotretsya podrostkam. [Professions of the future that teenagers should look at]. (2019). URL: https://hh.ru/article/25673 [in Russian].

Professii buduschego: na kogo uchitsya i kakie navyiki nuzhno razvivat uzhe segodnya [Professions of the future: who to study for and what skills need to be developed today]. (2019). URL: https://decedu.com/articles/professii-budushchego-na-kogo-uchitsya-i-kakienavyki-nuzhno-razvivat-uzhe-segodnya [in Russian].

Удк 378.093.5:373.2]:001.8(477)

DOI: https://doi.org/10.35387/od.1(19).2021.159-170

Іотковська

Олександрівна - аспірантка ДВНЗ «Донбаський державний педагогічний університет», м. Слов'янськ lotkovska Maryna - Postgraduate of the Department of Pedagogy of Higher School SHEl «Donbas State Pedagogical University», Slov'yansk

ORCID iD: https://orcid.org/0000-0002-7623-9996

E-mail: iotkovskamarina@ukr.net

\title{
МЕНТОРСЬКИЙ СУПРОВІД І РОЛЬ ОЧІЛЬНИКІВ КАФЕДР ДОШКІЛЬНОЇ ПЕДАГОГІКИ ЗАКЛАДІВ ВИЩОЇ ПЕДАГОГІЧНОЇ ОСВІТИ В УКРАЇ̈I (1991 - 2010 РP.)
}

Анотація. В оглядовій статmі досліджуються питання організації та досвіду наукової діяльності кафедр дошкільної педагогіки в закладах вищої педагогічної освіти України. Проаналізовано стан професійної діяльності колективу та очільників кафедр дошкільної ланки закладів вищої педагогічної освіти. Висвітлено наукові доробки в рамках окресленої проблеми та схарактеризовано еволюцію наукової думки. Акцентовано увагу на тих питаннях, які залишилися поза увагою вітчизняних дослідників на науковців сьогодення. Наголошено, що в науково-педагогічній літературі висвітлено окремі аспекти становлення й розвитку кафедр дошкільної педагогіки у структурі закладів вищої педагогічної освіти. Зазначено, що відсутність об'єктивної інтерпретації специфіки становлення й розвитку кафедр дошкільної освіти в системі вищої освіти України не дозволяє відтворити иілісну картину щодо особливостей їх розвитку, що спонукає до здійснення більш детального історико-педагогічного дослідження з метою вивчення 
науково-педагогічного досвіду із подальшим упровадженням його конструктивних ідей, що мають прогностичне значення. Зауважено, що за останні десятиріччя українська історико-педагогічна наука, зокрема дошкільна, переживає складні, суперечливі трансформації: відбуваються переосмислення наукових парадигм, а отже, й пошуку нових теоретикометодологічних орієнтирів. Акцентовано увагу на тому, що зростає потреба в оновленні змісту та напрямів наукової діяльності кафедр дошкільної педагогіки, що зафріксовано у відповідних законодавчих документах. Наголошено, що розвиток історико-педагогічної науки має практико орієнтовану спрямованість на очільника, тобто лідера, діяльність якого відповідає завданням удосконалення системи вищої освіти та дошкільного виховання у питаннях, окреслених в Законах України «Про освіту», «Про вищу освіту», Національній стратегії розвитку освіти в Україні на період до 2021 року.

Ключові слова: кафредра дошкільної педагогіки; завідувач кафредри, наукова думка; історико-педагогічний аналіз; науководослідницький потенціал, заклад вищої освіти.

lotkovska Maryna

\title{
MENTORING AND THE ROLE OF THE DEPARTMENT'S HEAD AT PRESCHOOL HIGHER PEDAGOGICAL EDUCATION OF UKRAINE
} (1991 - 2010)

\begin{abstract}
The review article investigates the issues of organization and experience of scientific activity of the departments of preschool pedagogy in institutions of higher pedagogical education of Ukraine. There is analyzed a state of professional activity of the staff and heads of the department of preschool level of the institutions of higher pedagogical education. The scientific achievements within the framework of the outlined problem are covered and the evolution of scientific thought on this problem is characterized too. The emphasis is placed on those issues that have remained out of the attention of domestic researchers and scholars of today. It is emphasized that in the scientific and pedagogical literature a certain amount of knowledge has been accumulated on the issues of development and formation of departments of preschool pedagogy in the structure of institutions of higher pedagogical education. The lack of an objective interpretation on the development and formation of the development and encourages a more detailed scientific, pedagogical, and historical analysis with the aim of an optimal reproducible experience, taking into account future developments and prospects. It is noted that in recent decades the Ukrainian historical and pedagogical science, in particular, in preschool education has undergone complex contradictory transformations: there is a rethinking of scientific paradigms, and the hence search for new theoretical and methodological guidelines. It is emphasized, that the development of historical and pedagogical science has a practice-oriented focus on the leader, whose activities meets the objectives of improving higher
\end{abstract}


education and preschool education, issues outlined in the Laws of Ukraine "On Education», "On Higher Education», National Development Strategy education in Ukraine for the period up to 2021.

Key words: a department of preschool pedagogy; a head of the department; the scientific opinion; the historical and pedagogical analysis; the research potential; an institution of higher education.

Постановка проблеми, ії актуальність. Пріоритетним напрямком освітньої політики України було завжди і залишається формування особистості здатної до творчої самореалізації та захисту національних інтересів, забезпеченні майбутнього розвитку нашої держави. Спираючись на історико-педагогічні здобутки, зокрема дошкільної системи освіти, як ії історично базової ланки, а також на гуманізацію та демократизацію наразі дедалі характернішим $€$ прагнення суспільства реалізації ідеї формування в молодого покоління шанобливого ставлення до норм та правил, які задекларовано й відбито в законодавчих актах і нормативних документах належного функціонування: Закон України «Про освіту» (2017), «Про дошкільну освіту» (зі змінами) (2001); Державний стандарт дошкільної освіти «Базовий компонент дошкільної освіти» (нова редакція) (2012), Національна стратегія розвитку освіти в Україні на 2012 - 2021 рр. (2012). Важливу роль у цьому процесі відіграють колективи кафедри як об'єднання представників професорсько-викладацького складу та наукових співробітників.

Однією з проблем, що не достатньо досліджена та висвітлена в теоретико-практичному аспекті, $€$ здійснення менторського супроводу, науково-дослідної діяльності колективу кафедр в закладі вищої педагогічної освіти, котрий має свої педагогічні, психологічні й організаційні особливості і потребує ґрунтовного вивчення. Тому проблема наставництва, менторського супроводу набуває особливої актуальності на етапі історико-педагогічного розвитку та розквіту кафедр дошкільної освіти у закладах вищої освіти в Україні.

У контексті викладеного вище значний науковий інтерес становлять питання щодо особистісного й профеесійного потенціалу завідувачів кафедр дошкільної педагогіки закладів вищої педагогічної освіти України. Вивчення порушених питань сприятиме об'єктивній оцінці історичної реальності, вияву впливу та значення окремих педагогічних ідей на фрормування й розвиток педагогічної думки, візуалізації доробку того чи іншого педагога-управлінця як індивідуального творця, виразника думки і практика своєї епохи (Башкір, 2017).

Отже, завданнями нашого наукового пошуку передбачено вивчення історичних закономірностей розвитку освіти, виховання, історії розвитку та становлення кафедр дошкільної педагогіки, аналіз професійної діяльності їх очільників у різні історичні періоди.

У зв'язку із вище сказаним доречно зосередити увагу на формуванні у студентів системи знань про світовий історико-педагогічний процес та місце дошкільної української педагогіки в ньому; ознайомити із 
формами виховання і педагогічними течіями через їх історичний аспект; розкрити кращі здобутки педагогічної мудрості українського народу та виробити вміння застосовувати їх у своїй майбутній професійній діяльності; сфрормувати самостійне історико-педагогічне мислення (навчити бачити й розуміти закономірності розвитку педагогічних категорій); фрормувати критичне ставлення до педагогічної спадщини минулого; оволодіти методами ретроспективного аналізу історико-педагогічних явищ і факторів; розширити науково-професійний світогляд, збагатити духовну культуру майбутніх педагогів (Артемова, 2006).

Аналіз останніх досліджень і публікацій. Звертаючись до наукової історико-педагогічної думки з питань дошкільної освіти та вищої педагогічної освіти загалом, тобто до використання доволі широкої джерельної пошукової бази, що саме і спричинило її умовний поділ на групи.

До першої групи включено матеріали архівних установ, а саме: Центрального державного історичного архіву України (ЦДІА України, м. Київ), Центрального державного архіву вищих органів влади та управління України (ЦДАВОУ України, м. Київ). Аналіз документів цієї групи дозволив зробити висновок, що вектори розбудови та розвитку системи вищої педагогічної освіти, зокрема дошкільної, визначалися пріоритетними сфрерами державної політики, однією з яких уважалася й вища педагогічна освіта, оскільки вона опосередковано впливає на процес фрормування особистості майбутніх громадян держави, їхнього світогляду, ідеалів, переконань.

Другу групу джерельної бази склали нормативно-правові документи в галузі дошкільної освіти на момент до 1991 р. та за часів незалежної України. Аналіз цієї інформації дозволив сформувати уявлення про нормативно-правову базу функціонування й розвитку системи вищої педагогічної освіти досліджуваного періоду, а також виокремити провідні тенденції розвитку освітнього простору діяльності колективу кафедр, зокрема дошкільної педагогіки, на чолі з їх лідерами 1991 - 2010 рр.

До третьої групи джерельної бази дослідження віднесено періодичні профрільні видання; наукові джерела педагогічного, історичного, психологічного, політологічного, соціально-економічного та філософського змісту; довідково-бібліографічна література, яка міститься в матеріалах фондів Центральної наукової бібліотеки НАН України ім. В.І. Вернадського, Харківської державної наукової бібліотеки ім. В.Г. Короленка, наукових бібліотек Луганського національного університету ім. Т.Г. Шевченка, Харківського національного університету ім. Г.С. Сковороди, Донбаського державного педагогічного університету.

Аналіз архівних матеріалів, історичної, політологічної, філософської, науково-педагогічної літератури, проведений у процесі дослідження теоретичних питань діяльності колективу кафедр дошкільної педагогіки у структурі закладів вищої педагогічної освіти, дозволив нам, з одного боку, дослідити процес розвитку освітнього простору кафедр дошкільної ланки означеного періоду, а з іншого, - визначити місце й роль 
у ньому їх очільників (Золотухіна, 2015).

Безперечний науковий інтерес для нашого дослідження мають точки зору щодо становлення й розвитку дошкільної педагогіки як науки, що знайшли відображення в працях Л. Артемової, А. Богуш, З. Борисової, О. Венгеловської, О. Лавріненка, О. Лугіної, Т. Степанової, І. Улюкаєвої, Л. Машкіної, С. Попиченко, О. Фунтікова та ін. Більшість учених доводить необхідність вивчення теоретико-методологічних та історико-філософрських засад досліджуваного питання, що відображено й розкрито у науковому доробку О. Адаменко, О. Антонової, Л. Березівської, М. Богуславського, С. Васильєвої, Л. Ваховського, С. Гончаренка, О. Гнізділової, Л. Гриневич, О. Донченко, Т. Пантюк, С. Саяпіної та ін.

Метою статті $€$ висвітлення проблем і перспектив науковопедагогічних пошуків колективів кафедр дошкільної освіти України, зумовлених професійною складовою діяльності їх завідувачів.

Виклад основного матеріалу дослідження. Актуальність дослідження реформаційних процесів розвитку суспільства завжди підвищується, оскільки такі часи в країні є перехідними, що ускладнює наукові пошуки. Серед перспективних напрямів розвитку науковопедагогічної діяльності кафредр дошкільної педагогіки в Україні в умовах історичних і сучасних викликів виокремлено освітню та науково-дослідну роботу, формування колективу, створення умов для особистісного зростання лідера, забезпечення стратегічного управління кафредрою (Золотухіна, 2011).

Вища школа, переорієнтовуючись на вимоги розбудови всіх сфер соціального життя держави, потребує нового ментора - фрахівця високого профресійного й культурного рівня, всебічно освіченого, компетентного, готового завжди оволодівати новими технологіями навчання й виховання. Це й зумовлює необхідність пошуку ефективних шляхів удосконалення професійно-педагогічної підготовки майбутніх педагогів, створення умов, що стимулюють професійне становлення особистості педагога.

Одним із шляхів вирішення вказаної проблеми $є$ детальне вивчення й творче переосмислення з сучасних позицій вітчизняного історичного досвіду, який дасть можливість здійснити об'єктивне висвітлення генези, змісту, напрямів діяльності колективу кафедр дошкільної освіти, визначити особливості їх функціонування на різних етапах розвитку вищої школи України, виявити чинники ефективної роботи з метою урахування педагогічно цінного досвіду та використати його в сучасних умовах (Біницька, 2013).

Зауважимо, що історія дошкільної педагогіки - це наука, що вивчає ретроспективу становлення та розвитку освітніх і виховних систем від найдавніших часів до сьогодення. У процесі аналізу історії розвитку освітнього простору кафедр дошкільної педагогіки та їх очільників було виявлено, що дослідження цінних надбань минулого як зарубіжної, так й української дошкільної педагогіки має важливе значення для відродження найкращих традицій в освіті та науці, підготовки наукових і науковопедагогічних кадрів, а отже, й виховання молоді. 
У контексті нашої роботи цілком логічним $є$ виокремлення кафедр дошкільної педагогіки як структурних одиниць кафредральної мережі закладів педагогічної освіти. Програмою нашого наукового дослідження було передбачено аналіз діяльності науково-педагогічного складу кафедр дошкільної педагогіки закладів вищої педагогічної освіти України упродовж $1991-2010$ pp.

Здійснений науковий пошук дає підстави для висновку про те, що наразі в Україні функціонує 41 заклад вищої педагогічної освіти, в яких здійснюється підготовка фрахівців із дошкільної освіти. У хронологічному вимірі нашого дослідження систематизовані назви відповідних кафедр у закладах вищої освіти наведено у табл. 1.

\section{Таблиця 1}

Заклади вищої освіти, в яких здійснювалася підготовка фахівців із дошкільної освіти в Україні (1991 - 2010 рр.)

\begin{tabular}{|c|c|}
\hline \multicolumn{2}{|r|}{ Заклади вищої освіти } \\
\hline Назва кафедри & Назва закладу \\
\hline $\begin{array}{l}\text { Кафедра дошкільної } \\
\text { освіти }\end{array}$ & 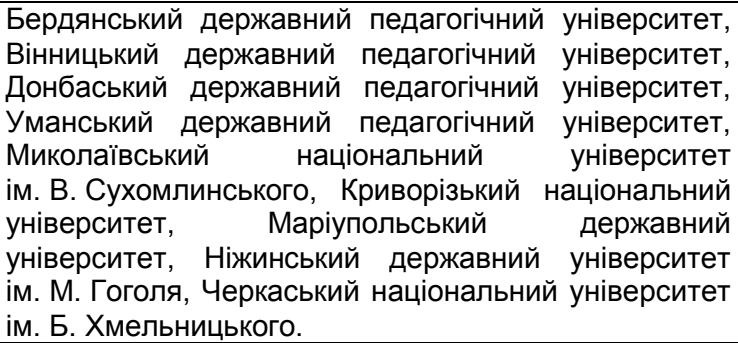 \\
\hline $\begin{array}{ll}\text { Кафедра дошкільної } \\
\text { освіти і соціальної } \\
\text { роботи }\end{array}$ & $\begin{array}{llr}\begin{array}{l}\text { Мелітопольський } \\
\text { університет, }\end{array} \text { державний } & \text { педагогічний } \\
\text { університет ім. Ю. Федькоцький } & \text { національний }\end{array}$ \\
\hline $\begin{array}{l}\text { Кафедра дошкільної } \\
\text { педагогіки і психології }\end{array}$ & $\begin{array}{l}\text { Глухівський національний педагогічний університет, } \\
\text { Переяслав-Хмельницький державний педагогічний } \\
\text { університет. }\end{array}$ \\
\hline $\begin{array}{lr}\text { Кафедра теорії } & \text { i } \\
\text { методики } & \text { із } \\
\text { дошкільної освіти } & \end{array}$ & $\begin{array}{l}\text { Прикарпатський національний університет імені } \\
\text { В. Стефаника, Кам'янець-Подільський національний } \\
\text { університет. }\end{array}$ \\
\hline $\begin{array}{l}\text { Кафедра психології і } \\
\text { педагогіки дошкільної } \\
\text { освіти }\end{array}$ & $\begin{array}{l}\text { Національний педагогічний } \quad \text { університет } \\
\text { ім. М.П. Драгоманова. }\end{array}$ \\
\hline $\begin{array}{lr}\text { Кафедра } & \text { педагогіки } \\
\text { та } & \text { психології } \\
\text { дошкільної } & \text { та } \\
\text { коррекційної ім. профр. } \\
\text { T. Поніманської }\end{array}$ & Рівненський державний гуманітарний університет. \\
\hline
\end{tabular}




\begin{tabular}{|c|c|}
\hline $\begin{array}{l}\text { Кафедра дошкільної } \\
\text { педагогіки та } \\
\text { методики навчання }\end{array}$ & $\begin{array}{l}\text { Східноєвропейський } \text { національний } \\
\text { ім. Л. Українки. }\end{array}$ \\
\hline $\begin{array}{lr}\text { Кафедра загальної } \\
\text { педагогіки } \\
\text { дошкільної освіти }\end{array}$ & $\begin{array}{l}\text { Дрогобицький державний педагогічний університет } \\
\text { ім. І. Франка. }\end{array}$ \\
\hline $\begin{array}{l}\text { Кафедра дошкільної } \\
\text { освіти та педагогічних } \\
\text { інновацій }\end{array}$ & Житомирський державний університет ім. І. Франка. \\
\hline $\begin{array}{l}\text { Кафедра психології } \\
\text { та педагогічної освіти }\end{array}$ & $\begin{array}{l}\text { Міжнародний класичний університет ім. Пилипа } \\
\text { Орлика. }\end{array}$ \\
\hline $\begin{array}{ll}\text { Кафедра } & \text { теорії та } \\
\text { методики } \\
\text { дошвіти }\end{array}$ & Харківська гуманітарно-педагогічна академія. \\
\hline $\begin{array}{lc}\text { Кафедра } & \text { теорії і } \\
\text { методики } & \text { початкової } \\
\text { освіти } & \end{array}$ & $\begin{array}{l}\text { Сумський державний педагогічний університет імені } \\
\text { А.С. Макаренка, Дніпровська академія неперервної } \\
\text { освіти, Львівський національний університет } \\
\text { ім. І. Франка, Ізмаїльський державний гуманітарний } \\
\text { університет, Кременецька обласна гуманітарно- } \\
\text { педагогічна академія ім. Т.Г. Шевченка. }\end{array}$ \\
\hline $\begin{array}{l}\text { Кафедра початкової } \\
\text { та дошкільної освіти }\end{array}$ & 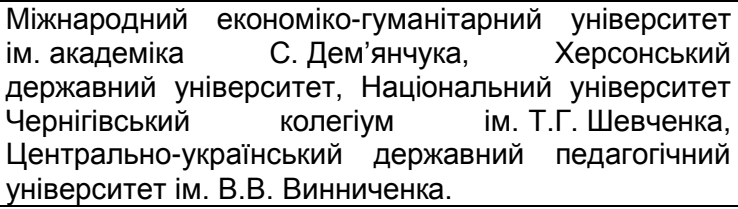 \\
\hline $\begin{array}{l}\text { Кафедра теорії і } \\
\text { технології дошкільної } \\
\text { освіти та мистецьких } \\
\text { дисциплін та кафедра } \\
\text { дошкільної педагогіки } \\
\text { і фрахових методик }\end{array}$ & $\begin{array}{l}\text { Харківський національний педагогічний університет } \\
\text { ім. Г.С. Сковороди. }\end{array}$ \\
\hline
\end{tabular}

Зауважимо, що кількість кафедр залежала від навчального плану й потреб в об'єднанні дисциплін для раціоналізації навчального процесу, від наявності кваліфікованого персоналу та бюджетних можливостей.

Особливу цінність для нашого дослідження становлять праці О. Башкір «Науково-педагогічна діяльність кафедр педагогіки у вищих навчальних закладах України (початок XX - XXIст.), О. Савченко «Теорія i практика розвитку вищої педагогічної освіти України в умовах інтеграційних процесів (кінець XX - початок XXI ст.)», С. Сисоєвої «Вища освіта України: реалії сучасного розвитку», Н. Терентьєвої «Тенденції розвитку університетської освіти в Україні (друга половина XX - початок XXI ст.)», В. Курила «Освіта України і науково-технічний та соціальний прогрес: історія, досвід, уроки».

Акцентуємо увагу на особливостях процесу, який відображає «нарощування» фрактографрічної бази та посилення наукового дискурсу, 
плюралізму думок і поглядів, поліфонії історико-педагогічних висновків. Установлено відсутність об'єктивного відтворення повноцінної картини розвитку потенціалу менторів кафедр дошкільної освіти, що спонукає до більш глибокого історико-педагогічного пошуку 3 метою врахування одержаних результатів у професійній підготовці сучасного вчителя.

Без сумніву, досвід науково-педагогічної роботи завідувачів кафедр дошкільної освіти періоду 1991-2010рр. має сприяти об'єктивній оцінці історико-педагогічної реальності й вияву, впливу та значення окремих педагогічних ідей на розвиток педагогічної науки, дошкільної педагогічної освіти в цілому. Соціальне становище, громадські позиції, рівень освіченості лідерів безпосередньо впливали на зміст науково-педагогічної діяльності кафедр дошкільної педагогіки (Гупан, 2001).

Уважаємо за доцільне взяти до уваги історію діяльності кафедри дошкільної освіти Миколаївського державного педагогічного університету, яка у вересні 2000 р. виокремилася у самостійний підрозділ закладу. Кафедру очолила доцент Т.Степанова. Упродовж усього етапу становлення та розвитку пліч-о-пліч з викладачами кафедри працювала академік НАПН України А. Богуш. Будучи науковим керівником, радником, колегою, науковиця сприяла професійному розвитку молодих фахівців, залучаючи їх до своєї наукової школи (Гнізділова, 2013). Наразі українське дошкілля поповнилося 8000 випускниками спеціальності 012 Дошкільна освіта, які обіймають адміністративні освітянські посади, а також працюють викладачами кафедр дошкільної освіти (А. Курчатова, Т. Лісовська, С. Тесленко, О. Супрунова та ін.).

Не менш важливим, на нашу думку, є досвід роботи колег кафедри дошкільної та початкової освіти Дніпровської академії неперервної освіти. Діяльність кафедри завжди була спрямована на підвищення рівня освіченості та професійної компетентності педагогічних працівників, ознайомлення із досягненням вітчизняної та світової педагогічної науки, практичне оволодіння сучасними освітніми методиками і технологіями, формування умінь творчо застосовувати інновації 3 метою реалізації загальноосвітніх навчальних завдань, підготовки до здійснення профрільного навчання (зав. кафедри В. Шинкаренко).

Зазначимо, що практика роботи зав. кафедри теорії і методики дошкільної та початкової освіти Т. Фасолько бере початок від циклової комісії психолого-педагогічних дисциплін Креманецького педагогічного училища, педагогічного коледжу, а згодом - гуманітарно-педагогічному інституті ім.Т.Г.Шевченка. Свого часу на кафедрі працювали: О. Макаренко, О. Бочелюк, О. Яловська, Л. Войтко, О. Цилепало, А. Калиноброцька, Т. Романюк, М. Майхрук, Н. Сабран. Метою кафедри $є$ забезпечення якісної професійної підготовки фахівців, згідно з галузевим стандартом вищої освіти, максимальне задоволення потреб студентів в отриманні відповідних професійних якостей, загальних і фахових компетенцій. На переконання колективу кафедри, особистісний потенціал утворюють індивідуальні здібності, які за певних умов проявляються у моральних вчинках, емоційно-вольових рішеннях 3 високим ступенем 
відповідальності (Саяпіна, 2016).

Наголосимо, що стратегія розвитку науково-педагогічної діяльності кафедр дошкільної педагогіки зумовлена системою цінностей, притаманних саме конкретній кафедрі, сумлінністю ставлення до виконання своїх професійних обов'язків, прагненням до позитивних змін, які є своєрідним дороговказом, керівництвом у діяльності.

У ході накового пошуку з'ясовано, що стратегія розвитку науковопедагогічної діяльності кафедр дошкільної освіти в Україні зумовлена перенасиченістю освітніх послуг державних і приватних закладів вищої освіти, підвищенням вимог до якості педагогічної освіти, новими технічними, методичними можливостями отримати освітні послуги і потребами населення в їхньому різноманітті, конкурентністю закладів вищої педагогічної освіти та їх очільників у боротьбі за потенційний контингент, вмотивованістю педагогічного персоналу, інтеграцією дисциплін, безпосередньо спрямованих на підготовку науково-педагогічних кадрів, незлагодженістю роботи кафедр, зокрема дошкільної ланки, із фраховими, відсутністю тісного взаємозв'язку з іншими освітніми установами (Вітвицька, 2005).

Висновки і перспективи подальших досліджень. Отже, аналіз освітньої, науково-педагогічної та інших видів діяльності кафедр дошкільної педагогіки у структурі закладів вищої педагогічної освіти України досліджуваного періоду характеризується спрямованістю педагогічної освіти на підготовку педагогічного й науково-педагогічного персоналу вищої ланки освіти, завданнями, поставленими перед педагогічною спільнотою щодо здійснення науково-педагогічних досліджень. Пріоритетними напрямами науково-педагогічної діяльності кафедр дошкільної освіти досліджуваного періоду були освітньо-виховний, науково-дослідний, зв'язок з освітніми установами та громадськістю, міжнародний та інноваційний розвиток.

На підставі аналізу соціально-економічних і культурно-освітніх чинників, законодавчих проєктів, внеску окремих науковців у розвиток дошкільної педагогічної освіти, виокремлено етапи розвитку кафедр дошкільної педагогіки вищих педагогічних закладів освіти України: I етап включає 60-70 роки XX ст., що є етапом зародження наукових досліджень у галузі дошкільної педагогіки; II етап - 80-ті роки XX ст. полягає у подальшому розвитку і офріційному визнанні здобутків наукових шкіл галузі дошкільної освіти, що позначився урізноманітненням та поглибленим вивченням тематики дослідницьких питань; та III етап, який повертає до 90-х рр. XX ст. - початок XXI ст., тобто перетворення однорівневих наукових шкіл, розширення напрямів науково-педагогічних досліджень, змістовного збагачення поля наукових пошуків (Стражнікова, 2013).

Наш науковий пошук, здійснений на основі аналізу відповідних першоджерел, засвідчив своєчасність й актуальність дослідження науковопедагогічної діяльності кафедр дошкільної педагогіки закладів вищої освіти України (1991-2010рр.), прогностичність, узгодженість отриманих результатів із наскрізними проблемами вищої педагогічної школи та 
вимогами і запитами суспільства щодо модернізації та інноваційного розвитку професійної підготовки майбутніх педагогічних і науковопедагогічних кадрів, а отже, й прогресивних очільників кафедр.

Одержані результати наукового пошуку уможливлюють висновки про те, що колективи кафедр дошкільної освіти досліджуваного періоду завжди активно працювали над удосконаленням методики викладання психолого-педагогічних дисциплін, пошуком шляхів досягнення єдності теоретично-практичної підготовки фахівців, організаціями навчальнометодичних семінарів для викладачів, підвищенням рівня власної професійної майстерності, розробкою науково-методичної, навчальної літератури для студентів і колег. Результатом науково-методичної роботи членів кафедр на чолі з їх завідувачами $є$ апробація дидактичних та інших напрацювань на семінарських заняттях, наукових конференціях різного масштабу тощо. Характерним стає налагодження на кафедрах дошкільної педагогіки процесу підготовки науково-педагогічних кадрів нового формату з урахуванням конструктивних ідей історико-педагогічного досвіду.

Проведена робота не вичерпує усіх аспектів досліджуваної проблеми. Перспективу подальшого наукового вивчення вбачаємо у дослідженні механізмів взаємодії очільників кафедр дошкільної освіти із науково-педагогічним складом кафедр у контексті вимог щодо організаційно-педагогічної, науково-дослідницької професійної діяльності.

\section{Список використаних джерел}

Артемова, Л.В. (2006). Історія педагогіки України: підручник. Київ: Либідь. Башкір, О.І. (2017). Науково-педагогічна діяльність кафедри педагогіки у вищих педагогічних навчальних закладах України: історикопедагогічний аспект: монографія. Харків: Видавництво Іванченка І.С. 518.

Біницька, К. (Ред.). (2013). Педагогічна історіографія - сучасний стан напрямку історико-педагогічних досліджень. Педагогічний дискурс: збірник наукових праць. Хмельницький: ХГПА, (15). 58-62.

Вітвицька, С.С. (2005). Практикум з педагогіки вищої школи: навчальний посібник. К.: Центр навчальної літератури.

Гнізділова, О. (2013). Грані науково-педагогічної діяльності академіка А.М. Богуш. Гуманітарний вісник ДВНЗ «ПереяславХмельницький державний педагогічний університет імені Григорія Сковороди». Додаток 1 до: 31, V (47): Тематичний випуск «Вища освіта України у контексті інтеграції до європейського освітнього простору». Київ: Гнозис, 112-121.

Гупан, Н.М. (2001). Розвиток історії педагогіки в Україні (історіографічний аспект): дис. ... д-ра пед. наук. Київ.

Золотухіна, С.Т. ( Ред.). (2011). Роль кафедри в підготовці наукових кадрів. Матеріали науково-практичного семінару деканів і завідувачів кафедр. Харків.

Золотухіна, С.Т. (2015). Напрями роботи кафедри педагогіки: досвід і перспективи. Педагогіка та психологія. Харків. (50), 182-190. 
Саяпіна, С.А. (2016). Публікації та дисертації вітчизняних авторів із питань виховання та навчання дітей дошкільного віку (1969 р. - початок XXI століття): бібліограф. покажчик. Слов'янськ. Б.І. Маторіна.

Стражнікова, І. (2013). Джерельна база історико-педагогічних досліджень Західного регіону України. Педагогічний дискурс: збірник наукових праць / гол. ред. І.М. Шоробура. Хмельницький: ХГПА, (15). 687691.

\section{References (translated and transliterated)}

Artemova, L.V. (2006). Istoriia pedahohiky Ukrainy [History of pedagogy of Ukraine]: pidruchnyk. Kyiv: Lybid [in Ukrainian].

Bashkir, O.I. (2017). Naukovo-pedahohichna diialnist kafedry pedahohiky u vyshchykh pedahohichnykh navchalnykh zakladakh Ukrainy: istorykopedahohichnyi aspect [Scientific-pedagogical activities of the department of pedagogy in higher pedagogical educational institutions of Ukraine: historical-pedagogical aspect]: monohrafiia. Kharkiv: Ivanchenko I.S. Publishing House [in Ukrainian].

Binytska, K. (2013). Pedahohichna istoriohrafiia - suchasnyi stan napriamu istorykopedahohichnykh doslidzhen [Pedagogical historiography - modern state of direction of historical-pedagogical studies]. Pedahohichnui dyskurs: zbirnyk naukovykh prats, 15, 58-62. Khmelnytskyi: KhHPA [in Ukrainian].

Vitvytska, S.S. (2005) Praktykum z pedahohiki vyshchoi shkoli [Workshop on higher school pedagogy]: navchalnyi posibnyk. Kyiv: Center for Educational Literature, 396 [in Ukrainian].

Hnizdilova, O. (2013). Hrani naukovo-pedahohichnoi diialnosti akademika A.M. Bohush [Facets of scientific-pedagogical activities of Academician A.M. Bohush]. Humanitarnyi visnyk DVNZ «Pereiaslav-Khmelnytskyi derzhavnyi pedahohichnyi universytet imeni Hryhoriia Skovorody». Dodatok 1 do: 31, V(47): Tematychnyi vypusk «Vyshcha osvita Ukrainy u konteksti intehratsii do yevropeiskoho osvitnoho prostoru», 112-121. Kyiv: Hnozys [in Ukrainian].

Hupan, N.M. (2001). Rozvytok istorii pedahohiky v Ukraini (istoriohrafichnyi aspect) [Development of history of pedagogy in Ukraine (historiographical aspect)]: Doctor's thesis. Kyiv [in Ukrainian].

Zolotukhina, S.T. (2011). Rol' kafedry v pidhotovtsi naukovykh kadriv [The role of the department in the training of scientific personnel]. Materialy naukovopraktychnoho seminaru dekaniv i zaviduvachiv kafedr [Proceedings of the scientific - practical seminar of deans and heads of departments] / (Ed.). Al. Prokopenko. Kharkiv, 359 [in Ukrainian].

Zolotukhina, S.T. (2015). Napryamy roboty kafedry pedahohiky: dosvid i perspektyvy [The directions of the Department of Pedagogy: experience and prospects]. Pedahohika ta psykholohiya - Pedagogy and psychology. Kharkiv. (50), 182-190 [in Ukrainian].

Saiapina, S.A. (2016). Publikatsii ta dysertatsii vitchyznianykh avtoriv iz pytan vykhovannia ta navchannia ditei doshkilnoho viku (1969 r. - pochatok XXI stolittia) [Publications and thesis of domestic authors on issues of upbringing and training preschool children (1969-the beginning of the 21st century)]: bibliograf. pokazhchyk. Sloviansk: B.I. Matorin Publishing House 
[in Ukrainian].

Strazhnikova, I. (2013). Dzherelna baza istoryko-pedahohichnykh doslidzhen Zakhidnoho rehionu Ukrainy [Source base of historical-pedagogical researches of the western region of Ukraine]. In I.M. Shorobura (Ed.). Pedahohichnyi dyskurs: zbirnyk naukovykh prats, 15, 687-691. Khmelnytskui: KhHPA [in Ukrainian].

УДК 378.014.61(485)(043.5)

DOI: https://doi.org/10.35387/od.1(19).2021.170-179

Kotun Kyryl - Candidate of Pedagocial Sciences (PhD in Pedagogy), Senior Researcher at Department of Pedagogical Education and Adult Education, Doctoral Student at Ivan Ziaziun Institute of Pedagogical Education and Adult Education of NAES of Ukraine
Котун Кирил Васильович кандидат педагогічних наук, старший науковий співробітник відділу зарубіжних систем педагогічної освіти $і$ освіти дорослих, докторант Інституту педагогічної освіти $i$ освіти дорослих імені Івана Зязюна НАПН України

ORCID iD: http://orcid.org/0000-0002-3661-6689

E-mail:smartk@ukr.net

\section{FEATHERS OF LIFELONG TEACHER EDUCATION IN SWEDEN}

Abstract. Nowadays, lifelong teacher education is an important lifelong learning component is conditioned not only by the dynamics of social, scientific and technological progress, changes in the scope and nature of work, increasing leisure time, and opportunities for its rational use but also by the social role of both society and personality. Quality education is considered by the world community as a tool of socio-economic growth and cultural development. Modern pedagogical reality is characterized by a tendency to find ways to improve higher education and reform. Sweden is one of the most developed socio-economic countries in the world. And the study of the experience of this particular country should help improve the training of native teachers. Teacher education in the Scandinavian countries has its own special socio-cultural significance and contains several dimensions that characterize the individual: education as an individual condition, education as an individual opportunity; education as an individual process; education as the highest value of mankind. It should be noted that the system of modern pedagogical education in Sweden is quite flexible and meets the needs of society in the number and qualifications of teachers. Also teacher has the opportunity in a lifelong pedagogical profile development. In order to ensure the continuous professional growth of teachers in Sweden, a system for improving their qualifications has been developed, regulated at various levels. That is why in conditions of integration processes, modernization of pedagogical education of Ukraine in accordance with the provisions of the Bologna 